\title{
BioLink
}

Jurnal Biologi Lingkungan, Industri, Kesehatan

Available online http://ojs.uma.ac.id/index.php/biolink

\section{ENVIRONMENTAL IMPACT OF CEMENT PRODUCTION ACTIVITIES IN BOOLANG REGENCY, MONGONDOW, NORTH SULAWESI}

\author{
Ilham Akbar Mustafa*, Hayati Sari Hasibuan, \& Ahyahudin Sodri \\ Environmental Science Study Program, Faculty of Environmental Science School, Universitas \\ Indonesia, Indonesia \\ Submited : 22-04-2021; Reviewed :12-06-2021; Accepted : 04-01-2022 \\ *Corresponding author: E-mail : m.ilhamakbar17@gmail.com
}

\begin{abstract}
The cement industry is a large industry that can have an impact on the surrounding environment. In the area of Boolang Regency, Mongondow, North Sulawesi, there is a foreign cement industry that has only been operating for about 2 years. Therefore, it is necessary to study the environmental impacts that have occurred around the cement industry. The objective of this study is to analyze the impact of the physical environment, especially water, on the production activities of the cement industry in Boolang Regency, Mongondow, North Sulawesi. The research method used was a laboratory test and the data were processed using STORET. The results showed that the water quality in the residents' wells was in very good condition, while the surface quality of the river water around the cement industry area could be categorized as lightly polluted.
\end{abstract}

Keywords: Cement Industry; Environmental Impact; Water

How to Cite: Mustafa, I. Akbar, Hasibuan, H.S., \& Sodri, A. (2022). Environmental Impact of Cement Production Activities in Boolang Regency, Mongondow, North Sulawesi, BioLink: Jurnal Biologi Lingkungan, Industri dan Kesehatan, Vol. 8 (2): Hal. 114-124 


\section{INTRODUCTION}

Industry is defined as a process to increase the value of an object or material so that it has more value compared to the original object (Ghazali et al. 2019). The cement industry in Indonesia is one of the strategic industries that are needed for infrastructure development such as buildings, ports, bridges, and so on(Pérez et al. 2017). Cement is used as the basic binding agent in concrete used for buildings, infrastructure and transportation systems around the world (Izumi et al. 2021). Based on its vital use, it is not surprising that in this era of development, one can find the wide spread of cement industry development in Indonesia. Currently, most of the cement industry in Indonesia is a medium and large scale industry with the highest production capacity reaching more than 35 million tons per year (Rayadi, 2019). The medium-scale cement production capacity ranges from 300,000-700,000 tons per year, while the large-scale cement industry has a production capacity of over 700,000 tons per year (Ishlah, 2008).

The construction of a new cement factory, of course, will have an impact on the environment and the community around the industry. Impact can be defined as a change that occurs as a result of certain activities. Activities can be categorized as natural which can be divided into chemical activities, physical activities, and biological activities (Thong et al. 2016). Industry and society are basically two elements that influence each other and cannot be separated (Rembet et al. 2018).

Globally, the negative impacts that may arise from the development of the cement industry, based on Githiria \& Onifade, (2020); Kabir \& Madugu, (2010) among them are the decline in environmental quality such as deforestation that causes soil disturbance and erosion as well as changes and loss of habitat for native fauna and flora, eutrophication of fresh water, acid flow and oxygen depletion in water that disrupt the chemical balance for aquatic wildlife, increased emissions that can affect climate change, as well as impacts on public health around the industry such as toxic dust particulates that can cause itching, respiratory diseases that can worsen asthma and bronchitis, and cancer. In addition, cement production also consumes a large amount of energy and natural resources, and accounts for about $7 \%$ of the world's greenhouse gas emissions (Fitryanti \& Fatimura, 2019).

On the other hand, based on Yan et al. (2009) the positive impacts that can be felt 
after the sustainable development of the cement industry include helping sustainable development for local communities, namely by opening up new job opportunities for affected local residents and increasing local residents' incomes, resulting in a cycle of mutualism with each other, namely social security and its environment. Building a community economy with less pressure on resources and the environment is an important challenge for the industry, indicating that the cement industry has been already running in a sustainable manner.(Liu et al. 2020). Mackley \& Milonas, (2001) states that sustainable development for cement production includes increasing the concentration of various compounds or substances at the actual value of nature and built through the surrounding environment. At the international level, the implementation of a sustainable cement industry has been outlined in a concept, namely the Cement Sustainable Initiative (CSI) which contains directives or 6 important points that are emphasized to realize a sustainable cement industry (Atasi, 2013). Indonesia has a green industry concept that can be applied in various industries including the cement industry by emphasizing waste management and the use of new and efficient technologies (Hutahaean, 2013).
Based on this background, it is necessary to conduct an environmental study as one of the supports for the concept of a sustainable industry for the development of the cement industry in Boolang Regency, Mongondow, North Sulawesi. It is expected that this research analysis can provide input as consideration for the cement industry players, as well as other stakeholders to overcome various problems or negative impacts faced, especially from the environmental side. Therefore, the objective of this study is to analyze the impact of the physical environment, especially water, from the production activities of the cement industry in Boolang Regency, Mongondow, North Sulawesi.

\section{MATERIALS AND METHODS}

This type of research generally used a quantitative approach. The research method usedwas a laboratory test and then the data were processed using the STORET method.

The research schedule was carried out for two months and started from November to December 2020. This research was carried out in two areas, namely: (1) around the cement factory area and (2) in residential areas around the cement factory. The selection of the research location was based on the fact that 
the place would later become an industrial area in eastern Indonesia.

The population and research sample related to the purpose of this environmental impact was water. The research population regarding the environmental impact on water quality

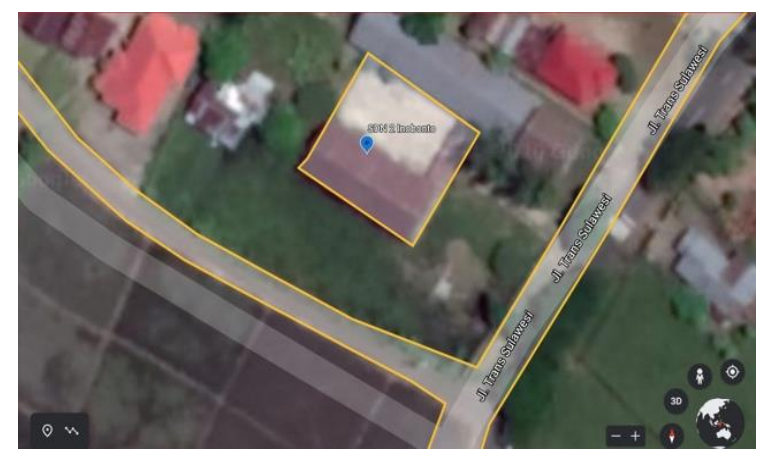

was divided into two, namely: (1) around the cement factory area, namely the surface of the river water in Mongondow and (2) residents' well water, namely water from the well of SDN 2 Inobonto, $1.2 \mathrm{~km}$ from the cement industry area.

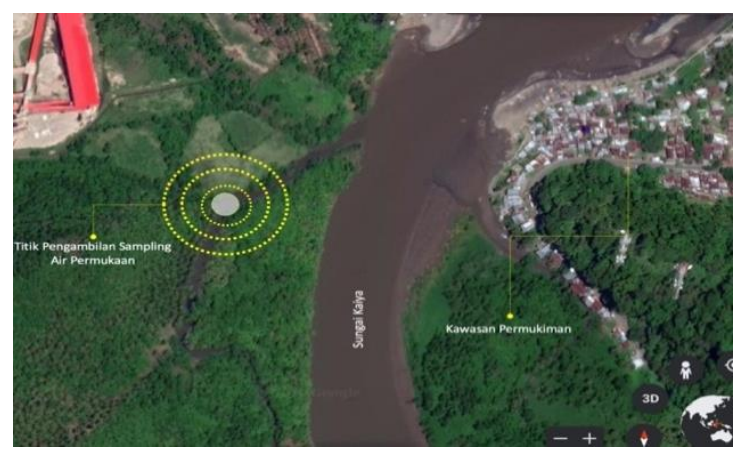

b

Figure 1. Sample Locations (a) Well Water at SDN 2 Inobonto (b) River in Mangrove Source: Google Earth, 2021

The coordinates of the river in Mangrove are 000 55'15.4" north, and 124004 ' 50.4" east, while the coordinates for community well water located at SDN 2 Inobonto well have location coordinates of 000 54'35.1" north , and 124025'24.8" east. The two water samples were selected using a random sampling method and tested in the laboratory with chemical parameters (BOD, COD, DO, pH, and metal elements) and physical parameters (color, temperature, TDS, and TSS).

The data collected in this study were divided into two, namely primary and secondary data, which can be described as follows:
1. Secondary Data: The results of laboratory tests on the quality of groundwater and river water around the cement industry area in 2016, 2017, 2018, and 2019 derived from the North Sulawesi DLH laboratory results document.

2. Primary Data: Laboratory tests of groundwater and river water quality around the cement industry area conducted in 2020.

After collecting primary data and secondary data, the next step is data processing. Processing of data obtained from the results of laboratory tests of water quality obtained from direct sampling of 
river surface water and groundwater exceeded water quality standards. The sources. Furthermore, groundwater and principle is the comparison between the river water samples were taken at random status of water quality and the results of and laboratory tests were carried out. The data obtained were processed using the STORET method.

The Storet method is one method that can be used to determine the status of the water quality test in the laboratory which is adjusted to its designation. The status of water quality used an assessment system from the US-EPA (Environmental water quality whether it has met or four water quality classes (Table 1).

Table 1. Class determination based on scores

\begin{tabular}{ccccl}
\hline No & Class & Condition & Score & \multicolumn{1}{c}{ Description } \\
\hline 1 & Class A & Very well & 0 & Meet quality standards \\
2 & Class B & Good & -1 to -10 & Slightly polluted \\
3 & Class C & Currently & -11 to -30 & Moderately polluted \\
4 & Class D & Bad & $>-31$ & heavily polluted \\
\hline
\end{tabular}

The method used in determining the status of water quality was the STORET method in accordance with the Decree of the Minister of the Environment No. 115 of 2003, are:

1. Collecting water quality and water discharge data periodically

2. Furthermore, the data obtained from the measurement results are compared with the quality standard values that have been set based on the class.

3. If the measurement result is less than or equal to the water quality standard, a score of 0 is given.

4. However, if the measurement result is greater than the water quality standard, a score is given based on Table 2 .

Table 2. Determination of the Value System to determine the Status of Water Quality

\begin{tabular}{clccc}
\hline $\begin{array}{c}\text { Number of } \\
\text { Samples }\end{array}$ & \multicolumn{1}{c}{ Mark } & Physics & $\begin{array}{c}\text { Parameter } \\
\text { Chemical }\end{array}$ & Biology \\
\hline$<10$ & Maximum & -1 & -2 & -3 \\
& Minimum & -1 & -2 & -3 \\
& Average & -3 & -6 & -9 \\
\hline$>10$ & Maximum & -2 & -4 & -6 \\
& Minimum & -2 & -4 & -6 \\
& Average & -6 & -12 & -18 \\
\hline
\end{tabular}

Source: Ministry of Environment Decree No. 115, 2003

\section{RESULTS AND DISCUSSION}

Environmental impact of production activities cement industry will be described further descriptively.

\section{Location at Sumur SDN 2 Inobonto}

Based on the results of laboratory tests of water quality with a point the first sample is at SDN 2 Inobonto well (Table 3) 
and the second sample point is at SDN 2

Inobonto (Table 4).

Table 3. Groundwater quality in the well of SDN 2 Inobonto

\begin{tabular}{cccccc}
\hline Parameter & Threshold & $\mathbf{2 0 1 6}$ & $\mathbf{2 0 1 7}$ & $\mathbf{2 0 1 9}$ & $\mathbf{2 0 2 0}$ \\
\hline TDS & $1000 \mathrm{mg} / \mathrm{l}$ & 353 & 167.4 & 161 & 359 \\
TSS & $50 \mathrm{mg} / \mathrm{l}$ & 3.2 & 3 & 3.3 & 4.6 \\
pH & $6-9$ & 6.9 & 7.3 & 6.9 & 7.68 \\
Ammonia (N-NH3) & n/a mg/l & 0.4 & 0.5 & 0.6 & 0.02 \\
Nitrate (HNO3) & $10 \mathrm{mg} / \mathrm{l}$ & 4.8 & 4.92 & 3.1 & 0.026 \\
Cyanide (total) & $0.02 \mathrm{mg} / \mathrm{l}$ & - & - & - & 0.005 \\
Fecal Coliform & $1000 \mathrm{mg} / \mathrm{l}$ & - & - & - & 3300 \\
Total Coliform & $5000 \mathrm{mg} / \mathrm{l}$ & - & - & - & 4900 \\
Mercury-Dissolved (Hg) & $0.002 \mathrm{mg} / \mathrm{l}$ & - & - & 0.000003 & 0.000005 \\
BOD & $3 \mathrm{mg} / \mathrm{l}$ & 2.9 & 2.9 & 2 & 2 \\
Dissolved Oxygen (DO) & $>4 \mathrm{mg} / \mathrm{l}$ & 6.74 & 6.47 & 7.48 & 7.57 \\
Zinc Dissolved (Zn) & $0.05 \mathrm{mg} / \mathrm{l}$ & 0.0218 & 0.02 & 0.004 & 0.004 \\
temperature & - & - & - & 28.1 & 28 \\
Cadmium (Cd) & $0.01 \mathrm{mg} / \mathrm{l}$ & - & - & 0.000004 & - \\
smell & - & - & - & no & no \\
flavor & - & - & - & no & Not \\
\hline
\end{tabular}

The results of the calculation of the condition means that the groundwater still water quality of the SDN 2 Inobonto well met the quality standards so that it did not through the STORET method, stated that need to be processed and could be used for the level of water contamination of the SDN various kinds of human needs such as 2 Inobonto well has a total score of 0 or fisheries, irrigation, to drinking water, and with very good condition status. This so on.

Table 4. STORET method for well water quality at SDN 2 Inobonto

\begin{tabular}{|c|c|c|c|c|c|c|c|c|c|}
\hline & \multirow{2}{*}{$\begin{array}{l}\text { Description } \\
\text { PHYSICS }\end{array}$} & \multirow{2}{*}{$\begin{array}{c}\text { Quality } \\
\text { standards }\end{array}$} & \multicolumn{6}{|c|}{ Measurement results } & \multirow{2}{*}{$\begin{array}{l}\text { Total } \\
\text { score }\end{array}$} \\
\hline & & & Min & Score & $\max$ & Score & Average & Score & \\
\hline 1 & TDS & $1000 \mathrm{mg} / \mathrm{l}$ & 161 & 0 & 359 & 0 & 260.1 & 0 & 0 \\
\hline 2 & TSS & $50 \mathrm{mg} / \mathrm{l}$ & 3 & 0 & 4.6 & 0 & 3,525 & 0 & 0 \\
\hline \multicolumn{10}{|c|}{ Chemical } \\
\hline 1 & $\mathrm{pH}$ & $6-9$ & 6.9 & 0 & 7.68 & 0 & 7,195 & 0 & 0 \\
\hline 2 & Nitrate (HNO3) & $10 \mathrm{mg} / \mathrm{l}$ & 0.026 & 0 & 4.92 & 0 & 3.2115 & 0 & 0 \\
\hline 3 & BOD & $3 \mathrm{mg} / \mathrm{l}$ & 2 & 0 & 2.9 & 0 & 2.45 & 0 & 0 \\
\hline 4 & $\begin{array}{l}\text { Dissolved Oxygen } \\
\text { (DO) }\end{array}$ & $>4 \mathrm{mg} / \mathrm{l}$ & 6.47 & 0 & 7.57 & 0 & 7,065 & 0 & 0 \\
\hline 5 & $\begin{array}{l}\text { Zinc Dissolved } \\
\text { (Zn) }\end{array}$ & $0.05 \mathrm{mg} / \mathrm{l}$ & 0.02 & 0 & 0.004 & 0 & 0.01245 & 0 & 0 \\
\hline 6 & $\begin{array}{l}\text { Mercury- } \\
\text { Dissolved (Hg) }\end{array}$ & $0.002 \mathrm{mg} / \mathrm{l}$ & 0.000003 & 0 & 0.000005 & 0 & 0.000004 & 0 & 0 \\
\hline
\end{tabular}

Source: Author's Results, 2020 
2. Location on River Surface in Mangroves

A tributary of the Mongondow River or commonly referred to by residents as the River in the Mangrove. The river in the Mangrove is a tributary of the Great Mongondow River. The river in the Mangrove was chosen because the river flows closest to and crosses the cement factory area. Sampling of the Sugai water surface in the Mangrove by researchers can be seen in Figure 3.

The samples taken were then tested in an environmental laboratory. Based on Table 5. Water Quality on River Surfaces in Mangroves

\begin{tabular}{lcccccc}
\hline \multicolumn{1}{c}{ Parameter } & $\begin{array}{c}\text { Quality } \\
\text { standards }\end{array}$ & $\mathbf{2 0 1 6}$ & $\mathbf{2 0 1 7}$ & $\mathbf{2 0 1 8}$ & $\mathbf{2 0 1 9}$ & $\mathbf{2 0 2 0}$ \\
\hline TDS & $1000 \mathrm{mg} / \mathrm{l}$ & 169 & 162 & 223 & 225 & 9910 \\
TSS & $50 \mathrm{mg} / \mathrm{l}$ & 32.9 & 25 & 28 & 14 & 26 \\
pH & $6-9$ & 7.19 & 7.46 & 7.36 & 7.05 & 7.73 \\
Ammonia (N-NH3) & n/a mg/l & 0.02 & 0.03 & 0.02 & 0.054 & 0.25 \\
Nitrate (HNO3) & $10 \mathrm{mg} / \mathrm{l}$ & 6.3 & 3.04 & 1.42 & 0.083 & 0.083 \\
BOD & $3 \mathrm{mg} / \mathrm{l}$ & 2.87 & 2 & 1.6 & 1.7 & 2 \\
COD & $25 \mathrm{mg} / \mathrm{l}$ & - & - & - & 6.35 & 10 \\
Dissolved Oxygen & $>4 \mathrm{mg} / \mathrm{l}$ & 6.32 & 6.8 & 7.1 & 5.3 & 6.83 \\
(DO) & & & & & & \\
Zinc (Zn) Dissolved & $0.05 \mathrm{mg} / \mathrm{l}$ & 0.00182 & 0.003 & 0.002 & 0.004 & 0.004 \\
temperature & & - & - & - & 27.8 & 28 \\
\hline
\end{tabular}

Source: Author's Results, 2020

The results of the calculation of river surface water quality using the STORET method (can be seen in Table 6), state that the level of river pollution in Mangroves has a total score of -2 or with the status of a lightly polluted condition. This condition using certain technologies.

means that the river water does not meet the quality standards set by the Government. Based on these conditions, the water on the surface of the river in the Mangrove can only be used by local the results of water quality laboratory tests with sampling points on the surface of the river in the Mangrove (Table 5).

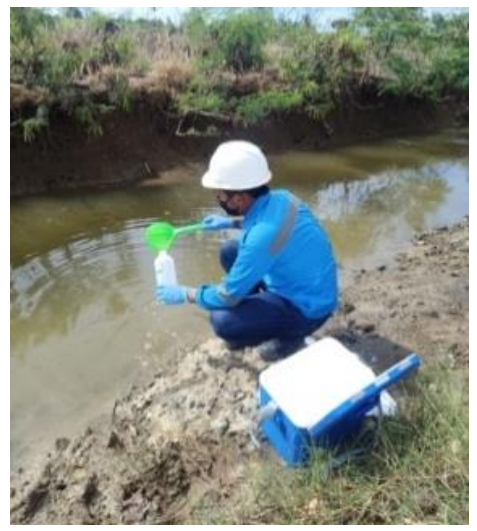

Figure 2. River Water Level in Mangroves 
Table 6. STORET Method for River Water Quality in Mangroves

\begin{tabular}{|c|c|c|c|c|c|c|c|c|c|}
\hline & \multirow{2}{*}{$\begin{array}{c}\text { Description } \\
\text { PHYSICS } \\
\end{array}$} & \multirow{2}{*}{$\begin{array}{c}\text { Quality } \\
\text { standards }\end{array}$} & \multicolumn{6}{|c|}{ Measurement results } & \multirow{2}{*}{$\begin{array}{l}\text { Total } \\
\text { score }\end{array}$} \\
\hline & & & Min & Score & mom & Score & Average & Score & \\
\hline 1 & TDS & $1000 \mathrm{mg} / \mathrm{l}$ & 162 & 0 & 9910 & -2 & 2137.8 & 0 & -2 \\
\hline 2 & TSS & $50 \mathrm{mg} / \mathrm{l}$ & 14 & 0 & 32.9 & 0 & 24,975 & 0 & 0 \\
\hline \multicolumn{10}{|c|}{ Chemical } \\
\hline 1 & $\mathrm{pH}$ & $6-9$ & 7.05 & 0 & 7.46 & 0 & 7,265 & 0 & 0 \\
\hline 2 & Nitrate (HNO3) & $10 \mathrm{mg} / \mathrm{l}$ & 0.083 & 0 & 6.3 & 0 & 2.2342 & 0 & 0 \\
\hline 3 & COD & $25 \mathrm{mg} / \mathrm{l}$ & 6.35 & 0 & 10 & 0 & 8,175 & 0 & 0 \\
\hline 4 & BOD & $3 \mathrm{mg} / \mathrm{l}$ & 1.6 & 0 & 2.87 & 0 & 2.034 & 0 & 0 \\
\hline 5 & Dissolved Oxygen (DO) & $>4 \mathrm{mg} / \mathrm{l}$ & 5.3 & 0 & 7.1 & 0 & 6,486 & 0 & 0 \\
\hline 6 & Zinc Dissolved (Zn) & $0.05 \mathrm{mg} / \mathrm{l}$ & 0.00182 & 0 & 0.004 & 0 & 0.002964 & 0 & 0 \\
\hline
\end{tabular}

Source: Author's Results, 2020

Based on the results of the two laboratory tests, namely (1) well water at SDN 2 Inobonto shows that the condition is in good condition; while (2) the river water level in the Mangrove shows that the condition is in a lightly polluted condition. The condition of well water at SDN 2 Inobonto and river water levels in Mangrove is described as follows:

a. TDS parameters. The maximum value from the results of laboratory tests for TDS levels on the river surface is 9910 $\mathrm{mg} / \mathrm{liter}$, while the maximum TDS content for SDN 2 Inobonto well water is $359 \mathrm{mg} /$ liter. Naturally, rocks and soil contain various minerals, but the Ministry of Environment has analyzed that the maximum TDS quality limit for water is $1000 \mathrm{mg} / \mathrm{l}$. Based on these data, it can be seen that the TDS value of the river surface in Mangarove in 2020 was 9 (nine) times above the environmental quality standard, it was very worrying because the presence of TDS in high concentrations in water bodies could cause the death of aquatic organisms. The TDS value that exceeded the quality standard could have a negative impact, namely it could reduce the ability of water bodies to balance the water ecosystem. TDS contained dissolved gases, organic substances, and inorganic substances. One of the possible indicators of high TDS in the river water surface in Mangroves was the presence of dissolved gases produced by the burning of cement industry raw materials (such as SOx, NOx, COx, and others). Based on Effendi (2003) states that if the TDS concentration is high, the water will become cloudy so that it can inhibit the photosynthesis process so that it is possible for heavy metals to react with toxic compounds which will cause the water temperature to increase. Water containing high TDS that exceeds the quality standards set by the government can also have a negative impact on human health. If 
TDS increases, the value of hardness in the water will also increase, this is due to the mineral content in the water. Boiling will not be able to reduce or eliminate the mineral content in the water, so that a special treatment was needed to reduce the TDS content such as the use of technology or water treatment installations.

b. Parameters Total suspended solids (TSS). The maximum value obtained from the results of laboratory tests for TSS levels on the river surface is $\mathbf{3 2 . 9}$ $\mathrm{mg} /$ liter, while the maximum TSS content for SDN 2 Inobonto well water is $4.6 \mathrm{mg} /$ liter. The TSS content is far below the environmental quality standard with a threshold of 50 $\mathrm{mg} / \mathrm{liter}$. The TSS value in water can be caused by sand or fine rocks, microorganisms, mud and so on. Based on Bilotta \& Brazier (2008) the content of TSS can affect physical, chemical, and biological changes in water resulting in decreased water quality. Although the results of the TSS content on the river surface still do not exceed the threshold, However, the condition of the water around the cement industrial area still needs to be considered to prevent the water condition from getting worse so that it can cause reduced sunlight entering the water so that it will affect the ecosystem in it. c. Nitrate Parameters. The maximum value from the results of laboratory tests for nitrate levels on the river surface is $6.3 \mathrm{mg} / \mathrm{liter}$, while the maximum Nitrate content for SDN 2 Inobonto well water is $4.92 \mathrm{mg} / \mathrm{liter}$. The nitrate content is still below the environmental quality standard with a threshold of $10 \mathrm{mg} /$ liter. The high nitrate content can come from the decomposition of waste containing organic nitrogen by microbes in the water. In addition to microbes, nitrogen oxidation reactions in the form of organic nitrogen such as amino acids, nitrites, ammonia, and so on can also make the nitrate content in water higher. The high content of nitrate compounds in water can cause algae to thrive (Sastrawijaya, 2009; Henri \& Ardiawati, 2020). High levels of nitrate in water sources or deep waters can reduce dissolved oxygen so that it endangers the life of aquatic biota.

d. BOD parameters. Biochemichal Oxygen Demand (BOD) is something that indicates the presence of dissolved oxygen needed by microorganisms or bacteria to decompose or decompose organic pollutants in water. The maximum value obtained from the results of the BOD laboratory test on the river surface is $2.87 \mathrm{mg} /$ liter, while the maximum BOD content for SDN 2 
Inobonto well water is $2.9 \mathrm{mg} / \mathrm{liter}$. The BOD content is close to the quality standard value of $3 \mathrm{mg} /$ liter. The BOD concentration value indicates that the water contains a fairly high concentration of organic matter. In line with Ali's opinion, the higher the concentration of organic matter in a water, the greater the concentration of BOD produced (Ali et al. 2013). It indicates that the two water qualities contain pollutants originating from organic matter, although the value is still below the quality standard. This high content of organic pollutants can cause decomposing bacteria to become active. The active decomposing bacteria or microbes can be biologically, namely through metabolic processes, they will convert these pollutants into organic acid compounds. The decomposition process carried out by microbes can be divided into two, namely aerobic and anaerobic, where the results of the decomposition of organic pollutants can produce side products in the form of methane, ammonia, and hydrogen sulfide which have a foul smell (Djarwanti et al. 2000).

DO parameters. The average DO value from the results of laboratory tests on the river surface is $6.48 \mathrm{mg} /$ liter, while the average BOD content for SDN 2 Inobonto well water is $7.065 \mathrm{mg} / \mathrm{liter}$. The BOD content is still good and in accordance with the quality standard value, namely $>4 \mathrm{mg} / \mathrm{liter}$, it indicates that the oxygen levels in both water quality are in good condition.

\section{CONCLUSION}

The water quality of the SDN 2 Inobonto well indicates very good condition, while the surface quality of the river water in the Mangrove was categorized as lightly polluted. Based on this, it can be concluded that the environmental conditions in the district of Boolang, Mongondow, North Sulawesi, were still quite good.

\section{REFERENCES}

Ali, A., Soemarno, \& Purnomo, M. (2013). Kajian Kualitas Air Dan Status Mutu Air Sungai Metro. Jurnal Bumi Lestari, 13(2), 265-274.

Atasi, Loubana. (2013). Environmental Impact Assessment for Sustainable Cement Productions. Thesis: Edinburgh Napier University

Bilotta GS, \& Brazier RE (2008). Understanding the Influence of Suspended Solid on Water Quality and aquatic biota. Water Research, 42 2849-2861. http://dx.doi.org/10.1016/j.watres.2008.03.01 8

Djarwanti, S. Cholid., dan Yuniati, Aniek., (200o). Degradasi Fotokatalitik Polutan Organik Dalam Air Limbah Menggunakan $\mathrm{TiO}_{2}$ Nano Partikel Sistem Lapisan Tipus-Alir. Balai Besar Teknologi Pencegahan Pencemaran Industri. Semarang.

Effendi, H. (2003). Telaah Kualitas Air bagi Pengelolaan Sumber Daya dan Lingkungan Perairan. Cetakan Kelima. Yogjakarta : Kanisius. 
Fitriyanti, R., \& Fatimura, M. (2019). Aplikasi Produksi Bersih Pada Industri Semen. Volume 3, Nomor 1, Januari-Juni 2019, 10-15

Ghazali, E. M., Nguyen, B., Mutum, D. S., \& Yap, S. F. (2019). Pro-environmental behaviours and Value-Belief-Norm theory: Assessing unobserved heterogeneity of two ethnic groups. Sustainability (Switzerland), 11(12), 1-28. https://doi.org/10.3390/su10023237

Githiria, J. M., \& Onifade, M. (2020). The impact of mining on sustainable practices and the traditional culture of developing countries. Journal of Environmental Studies and Sciences, $\quad 10(4), \quad 394-410$. doi.org/10.1007/s13412-020-00613-W

Henri, H., \& Ardiawati, S. (2020). ECOTOURISM DEVELOPMENT OF MUNJANG MANGROVE FOREST AND CONSERVATION EFFORTS BASED ON COMMUNITY APPROACH. BIOLINK : Jurnal Biologi Lingkungan Industri Kesehatan, $\quad$ 7(1), 106-116. doi:https://doi.org/10.31289/biolink.v7i1.295 2

Ishlah, T. (2008). Peluang Pendirian Industri Semen Sekala Kecil Di Kepulauan Maluku Dan Wilayah Papua. Buletin Sumber Daya Geologi, 3(3), 38-45. doi.org/10.47599/bsdg.v3i3.167

Izumi, Yoshito., Iizuka, Atsushi., \& Ho, Hsing-Jung. (2021). Calculation of greenhouse gas emissions for a carbon recycling system using mineral carbon capture and utilization technology in the cement industry. Journal of Cleaner Production, Volume 312, 20 August 2021, 127618 . doi.org/10.1016/j.jclepro.2021.127618

Kabir, G., \& Madugu, A. I. (2010). Assessment of environmental impact on air quality by cement industry and mitigating measures: A case study. Environmental Monitoring and Assessment, $\quad 160(1-4), \quad 91-99$. https://doi.org/10.1007/s10661-0o8-066o-4

Liu, Zhu., Ciais, Philippe., Deng, Zhu., Lei, Ruixue., Davis, Steven J., Feng, Sha., Zheng, Bo., Cui, Duo., Dou, Xinyu., Zhu, Biqing., Guo, Rui., Ke, Piyu., Sun, Taochun., Lu, Chenxi., He, Pan., Wang, Yuan., Yue, Xu., Wang, Yilong., Lei, Yadong., Zhou, Hao., Cai, Zhaonan., Wu, Yuhui., Guo, Runtao., Han, Tingxuan., Xue, Jinjun., Boucher, Olivier., Boucher Eulalie., Chevallier, Frédéric., Tanaka, Katsumasa., Wei, Yimin., Zhong, Haiwang., Kang, Chongqing., Zhang, Ning., Chen, Bin., $\mathrm{Xi}$, Fengming., Liu, Miaomiao., Bréon, François-Marie., Lu, Yonglong., Zhang,
Qiang., Guan, Dabo., Gong, Peng., Kammen, Daniel M., He, Kebin., \& Schellnhuber. Hans Joachim. (2020). Near-real-time monitoring of global $\mathrm{CO}_{2}$ emissions reveals the effects of the COVID-19 pandemic. Nature Communications, 11(1).doi:10.1038/s41467020-18922-7

Mackley, C. J., \& Milonas, S. (2001). Knowledge transfer and Green Building Challenge. Building Research and Information, 29(5), 346-354. doi.org/10.1080/o9613210110063791

Pérez, A., Santamaria, E. K., Operario, D., Tarkang, E. E., Zotor, F. B., Cardoso, S. R. de S. N., Autor, S. E. U., De, I., Dos, A., Vendas, O. D. E., Empresas, D. A. S., Atividades, P. O., Artigo, N., Gest, G. N. R. M. D. E., Para, D. E. F., Miranda, S. F. da R., Ferreira, F. A. A., Oliver, J., Dario, M., Volk, J. E. (2017). clinical guidelines for the management of hypertension [Internet]. Vol. 5, BMC Public Health. 2017. 1-8 p.

Rayadi, Wildan. (2019). Manajemen kolaborasi dalam pengelolaan lingkungan untuk mewujudkan pabrik semen ramah lingkungan. Jurnal Green Growth Dan Manajemen Lingkungan, Vol. 8. No.1, 1 Juli 19. p-ISSN: 2303-2332; e-ISSN: 2597-8020. doi.org/10.21009/jgg.081.03

Rembet, J. N., Sendow, M. M., \& Timban, J. F. J. (2018). Dampak Pembangunan Industri Pabrik Semen Terhadap Masyarakat Sekitar Di Desa Solog Kecamatan Lolak Kabupaten Bolaang Mongondow. Agri-SosioEkonomi Unsrat, ISSN 1907- 4298, Volume 14 Nomor 2, $\begin{array}{llllll} & \text { Mei } & 2018 \quad \text { : } & 221 & - & 228\end{array}$ https://doi.org/10.35791/agrsosek.14.2.2018.2 0586

Sastrawijaya AT. (2009). Pencemaran Lingkungan. Jakarta: Rineka Cipta.

Thong, N. T., Nguyen, D. H., Bich, P. T. N., \& Huong, L. T. M. (2016). Sustainable consumption and production in Vietnam. Sustainable Asia: Supporting the Transition to Sustainable Consumption and Production in Asian Developing Countries, 327-356. https://doi.org/10.1142/9789814730914_0013

Yan, Qishe., Zhou, Chang-Bo., Qu, Peng., \& Zhang, Rui. qin. (2009). The promotion of clean development mechanism to cement industry capturing waste heat for power generation in China. Mitigation and Adaptation Strategies for Global Change, 14(8), 793-804. Springer Science + Business Media

B.V. 2009https://doi.org/10.1007/s11027-0099199-o. 